\title{
UK clinical geneticists ask for ban on the patenting of human genes
}

London. The heads of four leading professional organizations of clinical geneticists have written a joint letter to the European Patent Office in Munich, as well as to senior UK government ministers, asking for a prohibition on the patenting of human genes.

Their demand comes at a time when representatives of the 12 member states of the European Union (EU) are discussing a new directive on biotechnology patents. In its current draft form, the directive would ban patents on gene fragments of unknown function; but it would allow patents on genes whose function is known, and whose potential utility - for example in diagnostic tests - can therefore be described.

This position is backed by many biotechnology companies, keen to exploit the commercial potential of new gene diagnostic and therapeutic techniques. It is also supported by the UK Medical Research Council, even though the council announced last month that it would no longer pursue patent applications for gene fragments (see Nature 366, 6; 1993).

But it is now being challenged in a statement agreed by three genetics organizations - the Clinical Genetics Society, the Clinical Molecular Genetics Society and the Association of Clinical Cytogeneticists - as well as the Genetics Nurses and Social Workers Association.

Their joint statement disagrees with the patenting of human genes on two grounds. One is the argument that it is morally unacceptable - and legally questionable - to patent an entity found in a natural state in the human body. (The draft EU directive excludes patents on "parts of the human body per se", but, according to Britain's Department of Trade and Industry, this exclusion would not cover a functioning human gene outside the body).

The second argument is that the ability to patent human genes is already making genetics researchers increasingly reluctant to share information, because this could undermine future patent applications on their work, and that a reluctance to communicate could lead to a delay in the discovery of new information about genetic diseases.

"My concern is that an excessive concentration by scientists on patenting will diminish the transfer of information, slow up the progress of science and delay the flow of useful information from the laboratories into the clinic," says Martin Bobrow, chairman of the division of medical and molecular genetics at Guy's and St Thomas's Medical School in London.

"Once people start getting too paranoid and looking over their shoulders all the time, it is likely to slow things down rather than speed things up," says Bobrow, who is also a member of the newly formed Gene Therapy Advisory Committee, and chairman of the committee that drew up the joint statement.

The clinical geneticists' statement adds substantial weight to a campaign against the patenting of human genes which is already gathering momentum among the charities that provide more than half of the funds used to support medical research projects in British universities.

Some of these charities, faced with the prospects of gaining extra income through patenting discoveries financed by their own funds - and acknowledging that this practice is already followed by other institutions - admit to being tempted to adopt the same

\section{IMAGE UNAVAILABLE FOR COPYRIGHT REASONS}

Pressure for secrecy 'could slow research on muscular dystrophy'.

stance as the MRC. But most argue that the commercial advantages of patent protection on individual genes are outweighed by other factors.

"The gene is a basic part of the human body," says Ann Hunt, chair of the Genetic Interest Group (GIG), an umbrella organization of almost a hundred voluntary groups concerned with genetic disorders. GIG has recently issued a position paper in which it argues that patents on genes are against the best interests of those suffering from genetic conditions.

"Quite apart from the ethical and moral objections that we have to the notion of anyone being allowed to own rights over something which is a fundamental part of all of us, we are also very concerned that this trend to patenting will slow down or even stop the development of gene therapy," says Hunt.

Several individual organizations belonging to GIG, such as the Muscular Dystrophy Group, have already taken a formal stand on the issue of gene patents. Many have been prompted to do so by the news earlier this year that the Children's Hospital in Toronto, whose researchers were the first to identify the main genetic mutation for cystic fibrosis, had been demanding royalty agreements from British researchers developing cystic fibrosis screening kits.

David Owen, who as director of technology licensing at the $\mathrm{MRC}$ is responsible for the council's patenting policy, says that the council does not agree with the antipatenting line being taken by GIG and others. He says that the question of whether genes should be patented has to be seen in the broader context of the practice and motivation of biotechnology companies.

Owen argues that patent protection is essential if companies are to develop diagnostic tests and new therapies for genetic disorders. "How can you give away [the use of] something that you do not own?" he asks. "We take the view that what is everybody's is nobody's."

But there is a growing feeling, for example among British scientists involved in the international Human Genome Project, that little would be lost - and much could be gained - through an international agreement permitting patents on new diagnostic tests and therapies, but not on the genetic information contained in these tests.

The issue of patents on genes is likely to be raised in a debate scheduled to take place in the House of Lords today (Thursday, 2 December). The Lords' Select Committee on Science and Technology is already looking at the issue known to be of interest to at least one member, Lord Walton - who is also on the national council of the Muscular Dystrophy Group.

Meanwhile the British debate is being watched carefully by senior officials of the European Commission in Brussels. Similar feelings have surfaced in other European countries; a proposal banning patents on human genes, for example, figures in a recent report to the French prime minister on bioethics. And the whole issue is likely to be debated again in the European Parliament when it discusses the final form of the new $\mathrm{EU}$ directive on biotechnology patents.

If the groundswell is strong enough, European countries could agree to include such a ban in the directive. But to be effective (and acceptable to industry) it would also be necessary to persuade other countries, in particular the United States, to adopt the same position. Some are suggesting that this is a task that could eventually be taken on by the Human Genome Organization.

David Dickson 